\title{
The Future of Prenatal Cytogenetics: From Copy Number Variations to Non-invasive Prenatal Testing
}

\author{
Paul Brady • Simon Ardui · Joris Robert Vermeesch
}

Published online: 4 April 2013

(C) Springer Science+Business Media New York 2013

\begin{abstract}
The conventional methods of prenatal diagnosis are being challenged by recent technologies. Chromosomal microarrays already in mainstream use for postnatal genetic diagnosis are increasingly used for prenatal diagnosis, mainly in pregnancies with sonographic anomalies but also for routine screening after any invasive procedure. Arrays have demonstrated the ability to detect submicroscopic copy number variations, providing an approximately $2.1 \%$ increase in the detection rate of pathogenic copy number variations regardless of the referral indication, and rising to an approximately $5.3 \%$ increase above conventional karyotyping in the presence of sonographic anomalies. More recently, novel technologies and methods of non-invasive prenatal testing are reaching clinical applications beyond fetal sex determination and rhesus blood group genotyping. Massively parallel sequencing methods have been shown to confidently detect trisomy 21 from cell-free DNA isolated from a maternal plasma sample and are rapidly entering clinical use. Targeted methods including epigenetic differences between the fetal and maternal genomes such as differential methylation are also being applied for non-invasive aneuploidy detection. It can be anticipated that very soon chromosomal microarrays will become the first-tier test for invasive prenatal diagnosis. In addition, we believe that non-invasive prenatal testing will gradually replace the need for invasive prenatal diagnosis with the associated risk of pregnancy loss.
\end{abstract}

P. Brady · S. Ardui · J. R. Vermeesch $(\varangle)$

Centre for Human Genetics, KU Leuven, University Hospital Leuven, O \& N I Herestraat 49, P.O. Box 602, 3000 Leuven, Belgium

e-mail: joris.vermeesch@uzleuven.be
Keywords Prenatal diagnosis - Copy number variation . Chromosomal microarrays $\cdot$ Non-invasive prenatal diagnosis · Cell-free fetal DNA · Massively parallel sequencing · Aneuploidy · Trisomy 21

\section{Introduction}

Conventional prenatal diagnosis relies on invasive procedures, such as amniocentesis or chorionic villi sampling, followed by genetic diagnostic tests. Karyotyping, typically by G-banding, was the gold standard for prenatal genetic diagnosis in the past decades. Although karyotyping provides genome-wide numerical and structural information, the resolution is limited to $5-10 \mathrm{Mb}$ at best, and culturing of cells is required, which requires at least 7-10 days. To overcome the resolution limitations and the time constraints of karyotyping, targeted analysis by cytogenetic and molecular-based methods has been introduced, such as fluorescence in situ hybridization and multiplex ligation-dependent probe amplification [1]. Although these techniques are capable of detecting submicroscopic imbalances, they rely on the presence of recognizable sonographic phenotypic features to direct the appropriate test to the relevant genomic locus.

Chromosomal microarrays are able to detect genomewide chromosomal imbalances or copy number variations (CNVs) and overcome most of the major limitations described above. One caveat is that arrays are unable to detect truly balanced rearrangements. However, the incidence of de novo balanced rearrangements is considered extremely low (less than $0.23 \%$ ) [2].

Non-invasive prenatal diagnostic technologies avoid the risks of miscarriages induced by invasive procedures and were long considered the "holy grail" for prenatal 
diagnosis. Those technologies have matured over recent years, and we will discuss the latest technological advances.

\section{Chromosomal Microarrays}

Chromosomal microarrays became the first-tier postnatal test for individuals with unexplained intellectual disability/ developmental delay, autistic spectrum disorders, or multiple congenital anomalies [3]. Despite the studies demonstrating the feasibility of prenatal diagnosis by chromosomal microarrays using a variety of platforms [48•], implementation for routine prenatal diagnosis has been slowly adopted because of ethical and counselling challenges $[7,9,10]$. The most recent studies are likely to remove those barriers and open the route towards routine clinical implementation.

\section{Genomic Array Platforms}

Oligonucleotide comparative genomic hybridization (CGH) arrays and single-nucleotide polymorphism (SNP) arrays are the two types of chromosomal microarrays that are currently in mainstream diagnostic use (reviewed in $[11,12])$. Oligonucleotide $\mathrm{CGH}$ arrays are built up from synthetic oligonucleotides with known genomic coordinates spotted onto a solid substrate. After both patient and reference DNA have been fluorescently labelled (typically with cyanine dyes $\mathrm{Cy} 3$ and $\mathrm{Cy} 5$ ), the samples are hybridized together onto the array, which allows competitive hybridization to the same targets (dual channel/dual colour). Gains and losses of genomic regions can subsequently be detected by measuring the fluorescent signal intensity ratios of patient DNA to reference DNA bound to the target oligonucleotides and by plotting the respective genomic position.

The second commonly used array platforms in prenatal diagnosis are SNP arrays. Unlike oligonucleotide $\mathrm{CGH}$ arrays, SNP arrays only need the patient DNA to be labelled before the sample is hybridized onto the array (single channel/single colour). This platform provides genotype information and permits the detection of copyneutral loss of heterozygosity, uniparental disomy and regions identical by descent by calculation of the B-allele frequency. In addition, gains and losses throughout the genome can be detected by comparing patient signal intensities with a reference set. Such a platform has great value as most laboratories are interested in detecting both copy number changes and loss of heterozygosity. Therefore, over recent years providers of oligonucleotide $\mathrm{CGH}$ arrays have improved their platforms so that they can also identify SNPs. The benefits of the inclusion of SNP probes include the ability to detect triploidy, uniparental isodisomy, and uniparental heterodisomy if parents are analysed on the same platform. SNP probes may also assist with detection of mosaicism, and can provide additional confirmation of CNVs detected by copy number probes on the same platform.

Arrays Reveal Additional Information Above Karyotyping

Arrays have been shown to provide an increase in the diagnostic yield by discovery of pathogenic submicroscopic CNVs undetectable by conventional karyotyping. Novel CNVs as well as known microdeletion and microduplication syndromes are observed. Arrays also provide additional valuable information over karyotyping. An array (1) provides a more precise delineation of breakpoints for structural rearrangements, allowing a more accurate assessment of gene content; (2) provides the precise identification of the origin of additional (euchromatic) chromosomal material; and (3) may reveal pathogenic imbalances at the rearrangement breakpoints in apparently balanced rearrangements. In addition, mosaicism can be detected by array analysis in the reduced dynamic range (signal intensity ratios with reduced deviation from $\log 2$ ratio of zero) for duplicated and deleted regions (and also by skewed B-allele frequencies on SNP arrays). Several studies have shown that detection of mosaicism at $10 \%$ levels is achievable [13-15].

\section{Results of Recent Prenatal Array Studies}

Over the past year, several large-scale prospective studies have reported on the use of arrays for routine prenatal diagnosis. The most recent includes a study of more than 4,000 pregnancies which reported that prenatal arrays provided additional clinically relevant information above karyotyping in $1.7 \%$ of pregnancies with standard referral indications (e.g. advanced maternal age, abnormal biochemical screen) and in $6.0 \%$ of cases with an anomaly on ultrasonography [16•]. A second large-scale study reported clinically significant CNVs in $5.3 \%$ of pregnancies referred for any indication and in $6.5 \%$ of pregnancies with abnormal ultrasound findings [8•]. A third study of more than 1,000 pregnancies reported a detection rate of $4.2 \%$ of clinically significant CNVs [7], with $1.7 \%$ undetectable by karyotyping. The detection of pathogenic CNVs in pregnancies without any sonographic anomalies argues for offering array analysis to any woman undergoing invasive testing.

We summarize the findings of these and other recent prenatal array studies in Table $1[7,8 \bullet, 15,16 \bullet, 17,18-$ 
20]. From the results from these studies, the increased detection rate of pathogenic $\mathrm{CNVs}$ above karyotyping alone is calculated to be approximately $2.1 \%$ regardless of the referral indication, rising to approximately $5.3 \%$ when the referral was due to abnormal ultrasound findings. Arrays increased the detection rate by $0.5-1.7 \%$ for lowerrisk referral indications such as advanced age or abnormal biochemical screen, with no abnormal ultrasound findings and a normal karyotype. Lee et al. [17] estimated the baseline risk of a pathogenic submicroscopic $\mathrm{CNV}$ to be approximately $0.52 \%$.

\section{Variants of Uncertain Significance}

In some cases array analysis may reveal an imbalance for known 'risk loci' where the future penetrance is uncertain, or is associated with variable expression. From the studies presented in Table 1, the risk of detection of a variant of uncertain significance is calculated to be in the range of $1.0-1.5 \%$. In the prenatal setting, it is at present impossible to predict the phenotypic outcome in the future child. The risk is currently based on the frequencies in cases and controls [21-23]. Although it is possible to calculate a population-based risk, it is currently impossible to identify which individuals will be affected. However, the family history and inheritance pattern may also assist in assessment of penetrance risk and phenotypic outcome.

\section{Non-invasive Prenatal Testing}

The initial work of Lo et al. [24] identified circulating cellfree fetal DNA in maternal plasma. Subsequently, this free fetal DNA was shown to be pregnancy-specific by rapid clearance from the maternal circulation after birth [25] and was derived from the trophoblast $[26,27]$. Cell-free DNA is fragmented with a size distribution of $160-180$ bp [28] and has been shown to be stable for a period of days after sampling [29], with one of the most important factors in maternal blood sampling being the prevention of maternal cell lysis leading to large levels of contaminating cellular DNA [30]. Although cell-free DNA is present in low proportions, from $3 \%$ to as much as $20 \%$ [31,32] against a high maternal DNA background, isolation of cell-free DNA has been shown to be feasible for a number of downstream applications of non-invasive prenatal testing (NIPT), including fetal sex assessment (review and metaanalysis in [33]) and fetal rhesus D blood group genotyping [34]. NIPT for single gene disorders has thus far been applied for the detection of a broad range of monogenic disorders, but was typically restricted to X-linked disorders or paternally inherited alleles (reviewed in [35]).
Advances in detection of fetal cells from maternal circulation have been less successful than for cell-free fetal nucleic acids since the numbers of fetal cells in maternal circulation are very low and their enrichment and subsequent culture remain challenging [36, 37]. Clearly, single-cell 'omics' analysis has great potential for NIPT if methods for isolation of fetal cells from the maternal circulation improve. Further research is needed to determine the correlation between individual circulating fetal cells and the true fetal genome. Since circulating cell-free DNA arises from many cells and also represents the entire fetal genome, this may prove to be more representative of the true fetal genome.

Non-invasive fetal aneuploidy detection by massively parallel sequencing was reported by two separate groups in 2008: Chiu et al. [38] in Hong Kong and Fan et al. [39] in Stanford. The massively parallel sequencing approach to aneuploidy detection applies counting statistics to tens or hundreds of millions of sequencing reads in order to identify respective changes in the small percentage of fetal DNA present in the total cell-free DNA sample [40, 41]. For example, if ten million mapped reads are obtained and $1 \%(100,000$ reads) map to chromosome 21 in a normal pregnancy, then a trisomy 21 pregnancy with a level of $10 \%$ free fetal DNA in maternal plasma will contribute a higher proportion of reads to chromosome 21 , in this case $1.05 \%$ (105,000 reads). With sufficient sequencing coverage (more than ten million reads) this small difference can be confidently detected in comparison with the mean and standard deviation of a normal cohort of pregnancies. Since these initial proof-of-principle studies, the industry has expanded dramatically, with some tests rapidly reaching clinical use in some countries. In one of the first largescale clinical validation studies, groups from the UK, the Netherlands, and Hong Kong demonstrated detection of trisomy 21 fetuses with $100 \%$ sensitivity and $97.9 \%$ specificity, which resulted in a positive predictive value of $96.6 \%$ and a negative predictive value of $100 \%$, using a duplex protocol [42•]. Duplex implies multiplexing of two samples labelled with unique DNA sequence indices clustered within a single lane of a sequencing flow cell. Multiplexing of samples reduces the cost per sample, but at the expense of lower sequencing coverage per sample. In comparison, the 8-plex protocol detected $79.1 \%$ of the trisomy 21 fetuses with $98.9 \%$ specificity, giving a positive predictive value of $91.9 \%$ and a negative predictive value of $96.9 \%$. Other studies have reported similar high levels of sensitivity and specificity and for additional chromosomes [43, 44] (reviewed in [45]).

In the largest study to date, Dan et al. [46•] recently reported on the clinical use of massively parallel sequencing for aneuploidy detection in cell-free DNA from maternal plasma in more than 11,000 pregnancies. In total, 
Table 1 Summary of the results from recent chromosomal microarray studies applied for prenatal diagnosis

\begin{tabular}{|c|c|c|c|c|c|c|c|}
\hline \multirow{2}{*}{$\begin{array}{l}\text { Total no. of } \\
\text { cases }\end{array}$} & \multirow[t]{2}{*}{ Overall detection rate ${ }^{\mathrm{a}}$} & \multicolumn{3}{|c|}{ Detection rate above karyotyping } & \multirow[t]{2}{*}{ VOUS } & \multirow{2}{*}{$\begin{array}{l}\text { Clinically significant } \\
\text { but unrelated to } \\
\text { phenotype }\end{array}$} & \multirow[t]{2}{*}{ Study } \\
\hline & & $\begin{array}{l}\text { Abnormal } \\
\text { US } \\
\text { findings }\end{array}$ & $\begin{array}{l}\text { AMA, high-risk } \\
\text { biochemical } \\
\text { screening }\end{array}$ & $\begin{array}{l}\text { Any } \\
\text { indication }\end{array}$ & & & \\
\hline $\begin{array}{l}4,282^{\mathrm{b}} \\
4,340 \text { total, } 58 \\
\text { mosaic } \\
\text { excluded }\end{array}$ & $\begin{array}{l}11.7(8.7 \%)^{\mathrm{c}} \\
(0.5 \%)^{\mathrm{d}}\end{array}$ & $6.0 \%$ & $\begin{array}{l}1.7 \% \text { AMA } \\
1.6 \% \text { screening }\end{array}$ & $2.5 \%$ & $1.5 \%$ & $\begin{array}{l}1.3 \% \mathrm{e} \text { normal } \\
\text { karyotype } \\
3.6 \% \text { abnormal US } \\
\text { findings } \\
0.8 \% \text { normal US } \\
\text { findings }\end{array}$ & $\begin{array}{c}\text { Wapner } \\
\text { et al. } \\
{\left[16^{\bullet}\right]}\end{array}$ \\
\hline $3,876^{\mathrm{b}}$ & NR & $\begin{array}{l}6.5 \% \\
(7.6 \%)^{\mathrm{f}}\end{array}$ & NR & $\begin{array}{l}5.3 \% \\
(6.5 \%)^{\mathrm{f}}\end{array}$ & $\begin{array}{l}4.2 \% \\
\quad(0.39 \%)^{\mathrm{g}}\end{array}$ & $1.3 \%$ & $\begin{array}{l}\text { Shaffer } \\
\text { et al. }[8 \bullet]\end{array}$ \\
\hline $1,075^{\mathrm{b}}$ & $\begin{array}{l}7.6 \% \text { total }(4.2 \% \\
\text { excluding known } \\
\text { abnormals) }\end{array}$ & NR & NR & $1.7 \%$ & $1.6 \%$ & NR & $\begin{array}{l}\text { Breman } \\
\text { et al. [7] }\end{array}$ \\
\hline 3,171 & $2.7 \%$ & NR & NR & $1.1 \%$ & $\begin{array}{l}0.6 \% \\
(0.2 \%)^{\mathrm{g}}\end{array}$ & $0.52 \%^{\mathrm{h}}$ & $\begin{array}{l}\text { Lee et al. } \\
\text { [17] }\end{array}$ \\
\hline 1,037 & $3.3 \%$ & NR & NR & $0.9 \%$ & $0 \%$ & NR & $\begin{array}{l}\text { Fiorentino } \\
\text { et al. } \\
{[15]}\end{array}$ \\
\hline 906 & $6.2 \%$ & $3.5 \%$ & $\begin{array}{l}1.1 \% \text { AMA } \\
0.4 \% \text { screening } \\
1.7 \% \text { anxiety }\end{array}$ & $1.6 \%$ & $1.9 \%$ & NR & $\begin{array}{l}\text { Armengol } \\
\text { et al. } \\
{[18]}\end{array}$ \\
\hline 4,073 & $1.8 \%$ & NR & NR & $0.27 \%$ & NR & NR & $\begin{array}{c}\text { Park et al. } \\
\text { [19] }\end{array}$ \\
\hline $751^{\mathrm{i}}$ & NR & $5.2 \%$ & NR & $3.6 \%$ & $1.1 \%$ & NR & $\begin{array}{l}\text { Hillman } \\
\text { et al. } \\
\text { [20] }\end{array}$ \\
\hline Average totals & & $5.30 \%$ & & $2.12 \%$ & $\begin{array}{l}1.56 \% \\
(0.96 \%)^{\mathrm{j}}\end{array}$ & & \\
\hline
\end{tabular}

US ultrasound, AMA advanced maternal age, VOUS variant of uncertain significance, $N R$ not reported

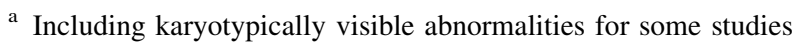

b Number of 'unbiased' cases used for calculations

c Automosomal or sex chromosome aneuploidies

${ }^{\mathrm{d}}$ Unbalanced rearrangements or marker chromosomes

${ }^{\mathrm{e}}$ Recurrent copy number variations (CNVs) associated with autism and neurocognitive alterations

${ }^{\mathrm{f}}$ Detection rate for oligonucleotide-based arrays only

g Percentage of VOUS occurring de novo

${ }^{\mathrm{h}}$ Baseline risk calculation for pathogenic $\mathrm{CNV}$ in pregnancies with no sonographic anomalies

i Ten studies included, eight studies used for meta-analysis

${ }^{\mathrm{j}}$ Using de novo VOUS values for calculation

143 cases of trisomy 21 and 47 cases of trisomy 18 were identified correctly, with one false-positive case of trisomy 21 , one false-positive case of trisomy 18 and no falsenegative cases, indicating $100 \%$ sensitivity and $99.96 \%$ specificity for the detection of trisomies 21 and 18. Routine clinical use could avoid about $98 \%$ of invasive prenatal diagnostic procedures.

Other approaches use targeted strategies for aneuploidy detection of chromosomes 13, 18, 21, X, and Y only. Those methods include the analysis of epigenetic differences between fetal and maternal cell-free DNA nucleic acids. One technique uses methylated DNA immunoprecipitation and real-time quantitative polymerase chain reaction (PCR) to identify differentially methylated regions between maternal and fetal cell-free DNA [47, 48, 49]. This technique was recently shown in a blinded validation study to detect trisomy 21 with $100 \%$ sensitivity and $99.2 \%$ specificity [50*0. An alternative approach uses a fetal-specific RNA-SNP target. The authors first looked for a messenger RNA (mRNA) which is transcribed from chromosome 21 , placental-specific 
and detectable in the maternal plasma. The PLAC4 mRNA fulfils these criteria and can be used to determine the dose of chromosome 21 by assessing the ratio between alleles of a specific SNP in the PLAC4 mRNA [51]. The aneuploidy status can be revealed by this technique since the allelic ratio will be 1:1 in a heterozygous euploid fetus, whereas it will be 2:1 or 1:2 in a heterozygous trisomic fetus. Lo et al. [51] investigated a cohort of 67 samples with informative SNPs, and showed that the RNA-SNP method detected trisomy 21 with $90 \%$ sensitivity and $96.5 \%$ specificity. However, an inherent drawback of the technique is that the aneuploidy status can only be determined if the fetus is heterozygous for the respective SNP under study. Tsui et al. [52] later tried to circumvent this drawback by determining the total PLAC4 mRNA concentration in maternal plasma by digital or realtime PCR. However, only moderate sensitivity and specificity is achieved by this method.

By more and deeper sequencing, not only aneuploidies but also other forms of structural variation could be detected. Srinivasan et al. [53 ••] detected microdeletions and duplications, as well as translocations, to $100-\mathrm{kb}$ binsize resolution. Recently, next-generation sequencing techniques have demonstrated the potential to detect maternally inherited alleles [54]. Lo et al. [55••] reported on the use of NIPT for construction of a genome-wide genetic map of the fetus, determining the mutational status of the fetus from cell-free fetal DNA in maternal plasma by using information on the paternal genotype and maternal haplotype. Kitzman et al. [56••] demonstrated non-invasive prediction of the fetal whole genome sequence using a combination of haplotype-resolved genome sequencing of the mother, whole-genome sequencing of the father, and deep sequencing of DNA isolated from maternal plasma. Prediction of paternal heterozygous sites was achieved with high accuracy (more than $98 \%$ ), but detection of de novo single-nucleotide variations was with very low specificity. Construction of the fetal haplotype has also recently been described without the necessity for paternal information [57••]. These types of approaches demonstrate the potential for non-invasive identification of maternally inherited and de novo variants in the fetus, as well as paternal variants, but further refinement is still needed to meet the requirements for clinical use.

Time is an important factor in prenatal diagnosis, allowing informed decisions to be made at the earliest opportunity. Arrays provide an ability to screen the entire genome for CNVs in as little as 2-3 days (more realistically 5-10 days in a routine setting) from direct fetal material, a significant advantage over karyotyping using cultured cells. However, the time necessary for library preparation, sequencing and subsequent bioinformatic analysis is a criticism of some current clinical NIPT applications.
The feasibility of NIPT with reduced time has been demonstrated with the Ion Torrent Personal Genome Machine sequencer [58] and it is likely that reports of studies using further emerging sequencing technologies will follow. One group demonstrated that the same fundamental principles of aneuploidy detection could also be applied to the Solid 4 system (Applied BioSystems) using ligation sequencing [27], aside from the Genome Analyzer and Hiseq platforms (Illumina) using sequencing-by-synthesis and which most researchers have used in published studies. Another group has also demonstrated the same principle of non-invasive aneuploidy detection using the Helicos platform [59]. Other novel 'third-generation' sequencing technologies, for example using nanopores or semiconductor chips, are reducing the time needed for both library preparations (using single-molecule sequencing without any amplification steps) and subsequent sequencing.

\section{Conclusion}

The general consensus is growing that arrays can be implemented in the prenatal setting. Those arrays provide a higher diagnostic yield, detecting submicroscopic CNVs as well as larger imbalances, and within a faster timeframe. The ethical concerns have long been hampering their introduction. There was (and still is) concern about how to deal with unsought findings, late onset disorders, CNVs with variable expressivity and penetrance and variants with mild phenotypic anomalies. Current experience reveals that the proportion of cases where difficulties in counselling arise is limited to $1-2 \%$. Nevertheless, more research and consensus guidelines in this area would help both clinicians and families. Because an invasive procedure is required, associated with a procedure-related risk, it seems likely that high-resolution chromosomal microarrays will mainly be offered for the analysis to those fetuses at significant increased risk of a chromosome abnormality.

Prenatal screening for aneuploidies will be performed using non-invasive tests. It seems likely that NIPT will also replace current biochemical testing and invasive methods of prenatal diagnosis. Price will determine whether the test will be provided for all pregnant women. Several hypothetical possibilities for introduction of NIPT into clinical practice have recently been reviewed [60], with the authors favouring a model that could be offered at 11-13 weeks' gestation, alongside existing combined screening, and accompanied by measures to maximize informed decisionmaking, including the provision of adequate pretest and posttest counselling. Many lawsuits are ongoing regarding patent infringement in the field of NIPT [61]. The outcomes of such lawsuits are likely to play an important role in the availability and the costs of different techniques for 
NIPT in the future. Hopefully, the potential lucrative NIPT market will drive competition and future development benefitting both research and clinical applications of NIPT and minimizing costs to health care services and consumers.

As discussed herein, the future possibilities for NIPT go far beyond aneuploidy detection in 'high-risk' pregnancies, and could allow CNV analysis, even fetal genome sequencing in 'low-risk' pregnancies given the lack of 'procedure-related' risks to the pregnancy. Considering that extensive deep sequencing is required, which comes with a significant cost, those techniques may not be routinely used in the coming years. Nevertheless, with everdecreasing sequencing costs, NIPT has the potential to make possible a full genome analysis and would thus be the ultimate prenatal genetic test.

The ethical questions posed and lessons learnt in the application of arrays to prenatal diagnosis will assist greatly as sequencing of the fetal genome by non-invasive methods moves closer to clinical applications. Additionally, the experience currently being gained in clinical diagnostic whole-genome/exome sequencing will assist in considering how these techniques can be best offered in the prenatal setting and ultimately for non-invasive prenatal diagnosis.

\section{References}

Papers of particular interest, published recently, have been highlighted as:

- Of importance

•- Of major importance

1. Goumy C, Gouas L, Pebrel-Richard C, Veronese L, EymardPierre E, Debost-Legrand A, Haoud K, Tchirkov A, Vago P. Prenatal detection of cryptic rearrangements by multiplex ligation probe amplification in fetuses with ultrasound abnormalities. Genet Med. 2010;12(6):376-80.

2. Hochstenbach R, van Binsbergen E, Engelen J, Nieuwint A, Polstra A, Poddighe P, Ruivenkamp C, Sikkema-Raddatz B, Smeets D, Poot M. Array analysis and karyotyping: workflow consequences based on a retrospective study of 36,325 patients with idiopathic developmental delay in the Netherlands. Eur J Med Genet. 2009;52(4):161-9.

3. Miller DT, Adam MP, Aradhya S, Biesecker LG, Brothman AR, Carter NP, Church DM, Crolla JA, Eichler EE, Epstein CJ, Faucett WA, Feuk L, Friedman JM, Hamosh A, Jackson L, Kaminsky EB, Kok K, Krantz ID, Kuhn RM, Lee C, Ostell JM, Rosenberg C, Scherer SW, Spinner NB, Stavropoulos DJ, Tepperberg JH, Thorland EC, Vermeesch JR, Waggoner DJ, Watson MS, Martin CL, Ledbetter DH. Consensus statement: chromosomal microarray is a first-tier clinical diagnostic test for individuals with developmental disabilities or congenital anomalies. Am J Hum Genet. 2010;86(5):749-64.
4. Coppinger J, Alliman S, Lamb AN, Torchia BS, Bejjani BA, Shaffer LG. Whole-genome microarray analysis in prenatal specimens identifies clinically significant chromosome alterations without increase in results of unclear significance compared to targeted microarray. Prenat Diagn. 2009;29(12):1156-66.

5. Faas BH, van der Burgt I, Kooper AJ, Pfundt R, Hehir-Kwa JY, Smits AP, de Leeuw N. Identification of clinically significant, submicroscopic chromosome alterations and UPD in fetuses with ultrasound anomalies using genome-wide 250k SNP array analysis. J Med Genet. 2010;47(9):586-94.

6. Srebniak M, Boter M, Oudesluijs G, Joosten M, Govaerts L, Van OD, Galjaard RJ. Application of SNP array for rapid prenatal diagnosis: implementation, genetic counselling and diagnostic flow. Eur J Hum Genet. 2011;19(12):1230-7.

7. Breman A, Pursley AN, Hixson P, Bi W, Ward P, Bacino CA, Shaw C, Lupski JR, Beaudet A, Patel A, Cheung SW, Van den Veyver I. Prenatal chromosomal microarray analysis in a diagnostic laboratory; experience with $>1000$ cases and review of the literature. Prenat Diagn. 2012;32(4):351-61.

8. - Shaffer LG, Dabell MP, Fisher AJ, Coppinger J, Bandholz AM, Ellison JW, Ravnan JB, Torchia BS, Ballif BC, Rosenfeld JA. Experience with microarray-based comparative genomic hybridization for prenatal diagnosis in over 5000 pregnancies. Prenat Diagn. 2012;32(10):976-85. This article presents one of the largest and most recent studies of chromosomal microarrays for routine prenatal diagnosis.

9. Vetro A, Bouman K, Hastings R, McMullan DJ, Vermeesch JR, Miller K, Sikkema-Raddatz B, Ledbetter DH, Zuffardi O, van Ravenswaaij-Arts CM. The introduction of arrays in prenatal diagnosis: a special challenge. Hum Mutat. 2012;33(6):923-9.

10. Wapner RJ, Driscoll DA, Simpson JL. Integration of microarray technology into prenatal diagnosis: counselling issues generated during the NICHD clinical trial. Prenat Diagn. 2012;32(4): 396-400.

11. Brady PD, Vermeesch JR. Genomic microarrays: a technology overview. Prenat Diagn. 2012;32(4):336-43.

12. Vermeesch JR, Brady PD, Sanlaville D, Kok K, Hastings RJ. Genome-wide arrays: quality criteria and platforms to be used in routine diagnostics. Hum Mutat. 2012;33(6):906-15.

13. Scott SA, Cohen N, Brandt T, Toruner G, Desnick RJ, Edelmann L. Detection of low-level mosaicism and placental mosaicism by oligonucleotide array comparative genomic hybridization. Genet Med. 2010;12(2):85-92.

14. Hoang S, Ahn J, Mann K, Bint S, Mansour S, Homfray T, Mohammed S, Ogilvie CM. Detection of mosaicism for genome imbalance in a cohort of 3,042 clinical cases using an oligonucleotide array CGH platform. Eur J Med Genet. 2011;54(2): 121-9.

15. Fiorentino F, Caiazzo F, Napolitano S, Spizzichino L, Bono S, Sessa M, Nuccitelli A, Biricik A, Gordon A, Rizzo G, Baldi M. Introducing array comparative genomic hybridization into routine prenatal diagnosis practice: a prospective study on over 1000 consecutive clinical cases. Prenat Diagn. 2011;31(13):1270-82.

16. - Wapner RJ, Martin CL, Levy B, Ballif BC, Eng CM, Zachary JM, Savage M, Platt LD, Saltzman D, Grobman WA, Klugman S, Scholl T, Simpson JL, McCall K, Aggarwal VS, Bunke B, Nahum O, Patel A, Lamb AN, Thom EA, Beaudet AL, Ledbetter DH, Shaffer LG, Jackson L. Chromosomal microarray versus karyotyping for prenatal diagnosis. $N$ Engl J Med. 2012;367(23):2175-84. This article presents one of the largest and most recent studies of chromosomal microarrays for routine prenatal diagnosis.

17. Lee CN, Lin SY, Lin CH, Shih JC, Lin TH, Su YN. Clinical utility of array comparative genomic hybridisation for prenatal diagnosis: a cohort study of 3171 pregnancies. BJOG. 2012;119(5):614-25. 
18. Armengol L, Nevado J, Serra-Juhe C, Plaja A, Mediano C, Garcia-Santiago FA, Garcia-Aragones M, Villa O, Mansilla E, Preciado C, Fernandez L, Angeles MM, Garcia-Perez L, Lapunzina PD, Perez-Jurado LA. Clinical utility of chromosomal microarray analysis in invasive prenatal diagnosis. Hum Genet. 2012;131(3):513-23.

19. Park SJ, Jung EH, Ryu RS, Kang HW, Ko JM, Kim HJ, Cheon CK, Hwang SH, Kang HY. Clinical implementation of wholegenome array $\mathrm{CGH}$ as a first-tier test in 5080 pre and postnatal cases. Mol Cytogenet. 2011;4(1):12.

20. Hillman SC, Pretlove S, Coomarasamy A, McMullan DJ, Davison EV, Maher ER, Kilby MD. Additional information from array comparative genomic hybridization technology over conventional karyotyping in prenatal diagnosis: a systematic review and metaanalysis. Ultrasound Obstet Gynecol. 2011;37(1):6-14.

21. Kaminsky EB, Kaul V, Paschall J, Church DM, Bunke B, Kunig D, Moreno-De-Luca D, Moreno-De-Luca A, Mulle JG, Warren ST, Richard G, Compton JG, Fuller AE, Gliem TJ, Huang S, Collinson MN, Beal SJ, Ackley T, Pickering DL, Golden DM, Aston E, Whitby H, Shetty S, Rossi MR, Rudd MK, South ST, Brothman AR, Sanger WG, Iyer RK, Crolla JA, Thorland EC, Aradhya S, Ledbetter DH, Martin CL. An evidence-based approach to establish the functional and clinical significance of copy number variants in intellectual and developmental disabilities. Genet Med. 2011;13(9):777-84.

22. Cooper GM, Coe BP, Girirajan S, Rosenfeld JA, Vu TH, Baker C, Williams C, Stalker H, Hamid R, Hannig V, Abdel-Hamid H, Bader P, McCracken E, Niyazov D, Leppig K, Thiese H, Hummel M, Alexander N, Gorski J, Kussmann J, Shashi V, Johnson K, Rehder C, Ballif BC, Shaffer LG, Eichler EE. A copy number variation morbidity map of developmental delay. Nat Genet. 2011;43(9):838-46.

23. Rosenfeld JA, Coe BP, Eichler EE, Cuckle H, Shaffer LG. Estimates of penetrance for recurrent pathogenic copy-number variations. Genet Med. 2012. doi:10.1038/gim.2012.164.

24. Lo YM, Corbetta N, Chamberlain PF, Rai V, Sargent IL, Redman CW, Wainscoat JS. Presence of fetal DNA in maternal plasma and serum. Lancet. 1997;350(9076):485-7.

25. Lo YM, Zhang J, Leung TN, Lau TK, Chang AM, Hjelm NM. Rapid clearance of fetal DNA from maternal plasma. Am J Hum Genet. 1999;64(1):218-24.

26. Alberry M, Maddocks D, Jones M, Abdel HM, Abdel-Fattah S, Avent N, Soothill PW. Free fetal DNA in maternal plasma in anembryonic pregnancies: confirmation that the origin is the trophoblast. Prenat Diagn. 2007;27(5):415-8.

27. Faas BH, de Ligt J, Janssen I, Eggink AJ, Wijnberger LD, van Vugt JM, Vissers L, van Geurts KA. Non-invasive prenatal diagnosis of fetal aneuploidies using massively parallel sequencing-by-ligation and evidence that cell-free fetal DNA in the maternal plasma originates from cytotrophoblastic cells. Expert Opin Biol Ther. 2012;12(Suppl 1):S19-26.

28. Fan HC, Blumenfeld YJ, Chitkara U, Hudgins L, Quake SR. Analysis of the size distributions of fetal and maternal cell-free DNA by paired-end sequencing. Clin Chem. 2010;56(8):1279-86.

29. Muller SP, Bartels I, Stein W, Emons G, Gutensohn K, Legler TJ. Cell-free fetal DNA in specimen from pregnant women is stable up to 5 days. Prenat Diagn. 2011;31(13):1300-4.

30. Barrett AN, Zimmermann BG, Wang D, Holloway A, Chitty LS. Implementing prenatal diagnosis based on cell-free fetal DNA: accurate identification of factors affecting fetal DNA yield. PLoS One. 2011;6(10):e25202.

31. Lo YM, Tein MS, Lau TK, Haines CJ, Leung TN, Poon PM, Wainscoat JS, Johnson PJ, Chang AM, Hjelm NM. Quantitative analysis of fetal DNA in maternal plasma and serum: implications for noninvasive prenatal diagnosis. Am J Hum Genet. 1998;62(4):768-75.
32. Lun FM, Chiu RW, Allen Chan KC, Yeung LT, Kin LT, Dennis Lo YM. Microfluidics digital PCR reveals a higher than expected fraction of fetal DNA in maternal plasma. Clin Chem. 2008;54 (10):1664-72.

33. Devaney SA, Palomaki GE, Scott JA, Bianchi DW. Noninvasive fetal sex determination using cell-free fetal DNA: a systematic review and meta-analysis. JAMA. 2011;306(6):627-36.

34. Finning KM, Martin PG, Soothill PW, Avent ND. Prediction of fetal D status from maternal plasma: introduction of a new noninvasive fetal RHD genotyping service. Transfusion. 2002;42 (8):1079-85.

35. Bustamante-Aragones A, de Rodriguez AM, Perlado S, TrujilloTiebas MJ, Arranz JP, Diaz-Recasens J, Troyano-Luque J, Ramos C. Non-invasive prenatal diagnosis of single-gene disorders from maternal blood. Gene. 2012;504(1):144-9.

36. Calabrese G, Baldi M, Fantasia D, Sessa MT, Kalantar M, Holzhauer C, Alunni-Fabbroni M, Palka G, Sitar G. Detection of chromosomal aneuploidies in fetal cells isolated from maternal blood using single-chromosome dual-probe FISH analysis. Clin Genet. 2012;82(2):131-9.

37. Huang Z, Fong CY, Gauthaman K, Sukumar P, Choolani M, Bongso A. Novel approaches to manipulating foetal cells in the maternal circulation for non-invasive prenatal diagnosis of the unborn child. J Cell Biochem. 2011;112(6):1475-85.

38. Chiu RW, Chan KC, Gao Y, Lau VY, Zheng W, Leung TY, Foo CH, Xie B, Tsui NB, Lun FM, Zee BC, Lau TK, Cantor CR, Lo YM. Noninvasive prenatal diagnosis of fetal chromosomal aneuploidy by massively parallel genomic sequencing of DNA in maternal plasma. Proc Natl Acad Sci USA. 2008;105(51): 20458-63.

39. Fan HC, Blumenfeld YJ, Chitkara U, Hudgins L, Quake SR. Noninvasive diagnosis of fetal aneuploidy by shotgun sequencing DNA from maternal blood. Proc Natl Acad Sci USA. 2008;105 (42):16266-71.

40. Chiu RW, Cantor CR, Lo YM. Non-invasive prenatal diagnosis by single molecule counting technologies. Trends Genet. 2009;25 (7):324-31.

41. Fan HC, Quake SR. Sensitivity of noninvasive prenatal detection of fetal aneuploidy from maternal plasma using shotgun sequencing is limited only by counting statistics. PLoS One. 2010;5(5):e10439.

42. • Chiu RW, Akolekar R, Zheng YW, Leung TY, Sun H, Chan KC, Lun FM, Go AT, Lau ET, To WW, Leung WC, Tang RY, Au-Yeung SK, Lam H, Kung YY, Zhang X, van Vugt JM, Minekawa R, Tang MH, Wang J, Oudejans CB, Lau TK, Nicolaides KH, Lo YM. Non-invasive prenatal assessment of trisomy 21 by multiplexed maternal plasma DNA sequencing: large scale validity study. BMJ. 2011;342:c7401. The is the first largescale validity study of NIPT using massively parallel sequencing for detection of trisomy 21.

43. Palomaki GE, Deciu C, Kloza EM, Lambert-Messerlian GM, Haddow JE, Neveux LM, Ehrich M, van den Boom D, Bombard AT, Grody WW, Nelson SF, Canick JA. DNA sequencing of maternal plasma reliably identifies trisomy 18 and trisomy 13 as well as Down syndrome: an international collaborative study. Genet Med. 2012;14(3):296-305.

44. Ehrich M, Deciu C, Zwiefelhofer T, Tynan JA, Cagasan L, Tim R, Lu V, McCullough R, McCarthy E, Nygren AO, Dean J, Tang L, Hutchison D, Lu T, Wang H, Angkachatchai V, Oeth P, Cantor CR, Bombard A, van den Boom D. Noninvasive detection of fetal trisomy 21 by sequencing of DNA in maternal blood: a study in a clinical setting. Am J Obstet Gynecol. 2011;204(3):205-11.

45. Verweij EJ, van den Oever JM, de Boer MA, Boon EM, Oepkes D. Diagnostic accuracy of noninvasive detection of fetal trisomy 21 in maternal blood: a systematic review. Fetal Diagn Ther. 2012;31(2):81-6. 
46. • Dan S, Wang W, Ren J, Li Y, Hu H, Xu Z, Lau TK, Xie J, Zhao W, Huang H, Xie J, Sun L, Zhang X, Wang W, Liao S, Qiang R, Cao J, Zhang Q, Zhou Y, Zhu H, Zhong M, Guo Y, Lin L, Gao Z, Yao H, Zhang H, Zhao L, Jiang F, Chen F, Jiang H, Li S, Li Y, Wang J, Wang J, Duan T, Su Y, Zhang X. Clinical application of massively parallel sequencing-based prenatal noninvasive fetal trisomy test for trisomies 21 and 18 in 11,105 pregnancies with mixed risk factors. Prenat Diagn. 2012;32(13):1225-32. This is the largest study to date of the clinical application of massively parallel sequencing for non-invasive prenatal diagnosis of trisomies 21 and 18.

47. Patsalis PC, Tsaliki E, Koumbaris G, Karagrigoriou A, Velissariou $\mathrm{V}$, Papageorgiou EA. A new non-invasive prenatal diagnosis of Down syndrome through epigenetic markers and real-time qPCR. Expert Opin Biol Ther. 2012;12(Suppl 1):S155-61.

48. Della RF, Mastrovito P, Campanile C, Conti A, Papageorgiou EA, Hulten MA, Patsalis PC, Carter NP, D'Esposito M. Differential DNA methylation as a tool for noninvasive prenatal diagnosis (NIPD) of $\mathrm{X}$ chromosome aneuploidies. J Mol Diagn. 2010;12(6):797-807.

49. Papageorgiou EA, Karagrigoriou A, Tsaliki E, Velissariou V, Carter NP, Patsalis PC. Fetal-specific DNA methylation ratio permits noninvasive prenatal diagnosis of trisomy 21 . Nat Med. 2011;17(4):510-3.

50. • Tsaliki E, Papageorgiou EA, Spyrou C, Koumbaris G, Kypri E, Kyriakou S, Sotiriou C, Touvana E, Keravnou A, Karagrigoriou A, Lamnissou K, Velissariou V, Patsalis PC. MeDIP real-time qPCR of maternal peripheral blood reliably identifies trisomy 21 . Prenat Diagn. 2012;32(10):996-1001. This article describes the clinical validation of the targeted methylated DNA immunoprecipitation real-time quantitative PCR approach to non-invasive prenatal diagnosis of aneuploidy.

51. Lo YM, Tsui NB, Chiu RW, Lau TK, Leung TN, Heung MM, Gerovassili A, Jin Y, Nicolaides KH, Cantor CR, Ding C. Plasma placental RNA allelic ratio permits noninvasive prenatal chromosomal aneuploidy detection. Nat Med. 2007;13(2):218-23.

52. Tsui NB, Akolekar R, Chiu RW, Chow KC, Leung TY, Lau TK, Nicolaides KH, Lo YM. Synergy of total PLAC4 RNA concentration and measurement of the RNA single-nucleotide polymorphism allelic ratio for the noninvasive prenatal detection of trisomy 21. Clin Chem. 2010;56(1):73-81.

53. • Srinivasan A, Bianchi DW, Huang H, Sehnert AJ, Rava RP. Noninvasive detection of fetal subchromosome abnormalities via deep sequencing of maternal plasma. Am J Hum Genet. 2013;92(2):167-76. This article describes the use of deep sequencing for detection of submicroscopic CNVs in cell-free fetal DNA isolated from maternal plasma. The authors detected microdeletions and duplications, as well as translocations.

54. Tsui NB, Kadir RA, Chan KC, Chi C, Mellars G, Tuddenham EG, Leung TY, Lau TK, Chiu RW, Lo YM. Noninvasive prenatal diagnosis of hemophilia by microfluidics digital PCR analysis of maternal plasma DNA. Blood. 2011;117(13):3684-91.

55. • Lo YM, Chan KC, Sun H, Chen EZ, Jiang P, Lun FM, Zheng YW, Leung TY, Lau TK, Cantor CR, Chiu RW. Maternal plasma DNA sequencing reveals the genome-wide genetic and mutational profile of the fetus. Sci Transl Med. 2010;2(61):61-91. This article describes the use of massively parallel sequencing of cellfree DNA to identify fetal-specific mutations.

56. •• Kitzman JO, Snyder MW, Ventura M, Lewis AP, Qiu R, Simmons LE, Gammill HS, Rubens CE, Santillan DA, Murray JC, Tabor HK, Bamshad MJ, Eichler EE, Shendure J. Noninvasive whole-genome sequencing of a human fetus. Sci Transl Med. 2012;4(137):137ra76. This article describes the use of massively parallel sequencing of cell-free DNA to identify both inherited and de novo fetal-specific mutations.

57. • Fan HC, Gu W, Wang J, Blumenfeld YJ, El-Sayed YY, Quake SR. Non-invasive prenatal measurement of the fetal genome. Nature. 2012;487(7407):320-4. This article describes the use of massively parallel sequencing of cell-free DNA to identify fetalspecific mutations, and reconstruction of the fetal haplotype without the necessity for paternal information.

58. Yuan Y, Jiang F, Hua S, Du B, Hao Y, Ye L, Liu J, Feng K, Huang X, Yi X, Wang W, Yang L, Mu F, Liu C, Liang Y. Feasibility study of semiconductor sequencing for noninvasive prenatal detection of fetal aneuploidy. Clin Chem. 2013. doi: 10.1373/clinchem.2012.196725.

59. van den Oever JM, Balkassmi S, Verweij EJ, van Iterson M, van Adama PN, Oepkes D, van Lith JM, Hoffer MJ, den Dunnen JT, Bakker E, Boon EM. Single molecule sequencing of free DNA from maternal plasma for noninvasive trisomy 21 detection. Clin Chem. 2012;58(4):699-706.

60. Deans Z, Newson AJ. Ethical considerations for choosing between possible models for using NIPD for aneuploidy detection. J Med Ethics. 2012;38(10):614-8.

61. Hayden EC. Fetal tests spur legal battle. Nature. 2012;486(7404):454. 